\title{
Carcinoma Simplex
}

National Cancer Institute

\section{Source}

National Cancer Institute. Carcinoma Simplex. NCI Thesaurus. Code C65195.

An undifferentiated malignant epithelial neoplasm which tends to infiltrate the surrounding tissues and spread to other anatomic sites. 